\title{
THE SLANTED CAPILLARY METHOD OF RHESUS BLOOD-GROUPING
}

\author{
BY \\ BRUCE CHOWN AND MARION LEWIS \\ From the Department of Paediatrics, University of Manitoba, and the Rh Laboratory \\ at the Children's Hospital, Winnipeg, Canada
}

(RECEIVED FOR PUBLICATION JUNE 29, 1951)

In 1944 a method of $\mathrm{Rh}$ blood-grouping, using slanted capillary tubes, was described (Chown, 1944). Further experience with the method led to the appreciation of certain errors in it, which, in 1946, we pointed out, together with ways of preventing them (Chown and Lewis, 1946). Although Discombe and Meyer (1948) reported favourably on the revised method, descriptions of the original one remained more readily available in Britain (Mollison, Mourant, and Race, 1948 ; Pickles, 1949 ; Poole and Williams, 1951), so that, because of the inherent errors in this form, the method in any form fell into disrepute.

We have used the revised method on many thousands of blood samples, and believe that, properly carried out, it is simple, rapid, accurate, and economical for Rh-grouping. The slanted capillary has further advantages and uses which we shall report on later.

\section{Accuracy of the Method}

Since we do not do $\mathrm{Rh}$-grouping by any test-tube method we can offer, as proof of the accuracy of our method, only comparisons with the results of others who do. The following three studies are so offered.

In 1949, as part of a study of the $\mathrm{Rh}$ chromosome distribution of the white population of the Province of Manitoba, we tested, with anti-C, anti-D, anti-E, and anti-c, 792 unselected individuals of English descent (Chown, Peterson, Lewis, and Hall, 1949). Our results are compared in Table I with those of Race, Mourant, Lawler, and Sanger (1948), who tested 2,000 English people by their test-tube method. (A test for homogeneity gives $\chi^{2}=7.711$; d.f. $=9 ; P=0.5$.) The two series do not differ significantly in distribution of $\mathrm{Rh}$ phenotypes. From this we deduce that the two methods of testing give closely comparable results.

In 1949 Dr. Philip Levine, of the Ortho Research Foundation, generously gave us some of his anti-k serum "Cellano." With this serum Levine, Backer, Wigod, and Ponder had tested 2,500 unselected white Americans. With it we (Chown, Lewis, and Peterson, 1951) tested 2,872 unselected white Canadians. The results are compared in Table II $\left(\chi^{2}=0.1108\right.$; d.f. $\left.=1 ; \mathbf{P}=0.07\right)$. Again the results do not differ significantly, so that we deduce that the two methods give comparable results.

Dunsford (1949) and Bertinshaw, Lawler, Holt, Kirman, and Race (1950) tested 1,041 English people with Dunsford's anti-K serum "And." We tested the above 
TABLE I

Results of Rh Test in England by Test-tube Method and in Canada by the CAPILlaRY MeTHOD

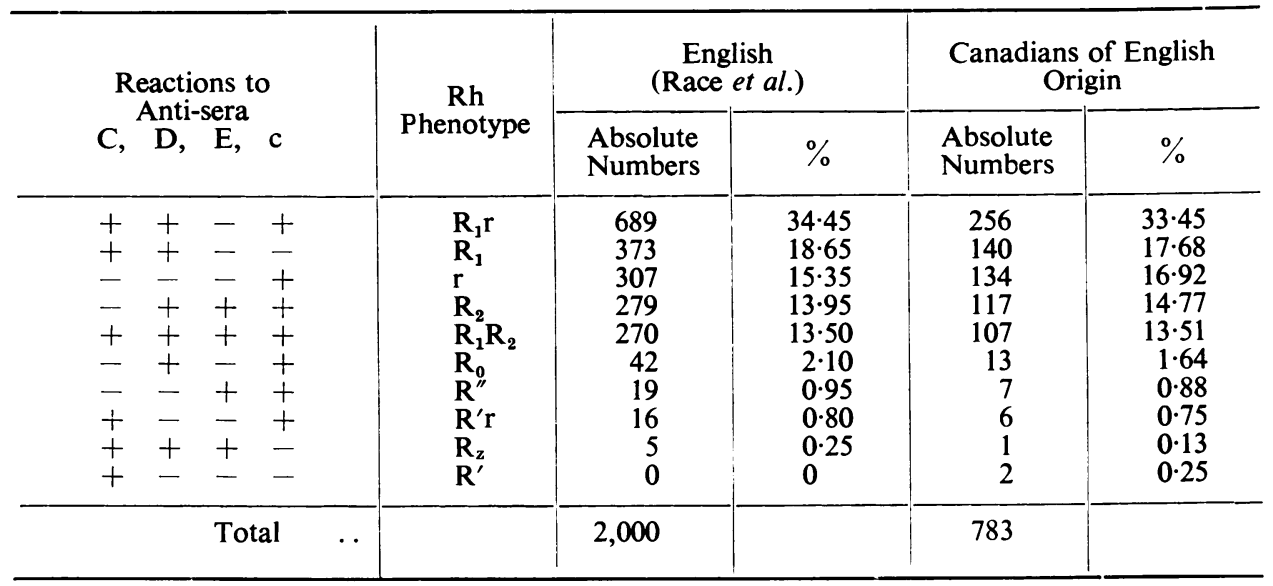

TABLE II

Results of Tests with Anti-Cellano Serum in the United States by the Test-tube Method aNd IN CANADA BY THE CAPILlaRY METHOD

\begin{tabular}{c|c|c}
\hline $\begin{array}{c}\text { Reactions to } \\
\text { Anti-Cellano }\end{array}$ & $\begin{array}{c}\text { Americans } \\
\text { (Levine } \text { et al. })\end{array}$ & Canadians \\
\hline+ & 2,495 & 2,865 \\
7
\end{tabular}

2,872 white Canadians with our anti-K serum "Ram." The results are compared in Table III $\left(\chi^{2}=0.0543\right.$; d.f. $\left.=1 ; \mathrm{P}=0.8\right)$. Again, since the results do not differ significantly, we deduce that the two methods give comparable results.

TABLE III

Results of Tests with ANTI-K (AND) by the Test-tube AND with ANTI-K (Ram) by THE CAPILlary MeTHODS

\begin{tabular}{c|c|c}
\hline $\begin{array}{c}\text { Reactions to } \\
\text { Anti-K }\end{array}$ & $\begin{array}{c}\text { " And " } \\
\text { (Bertinshaw et al. and Dunsford) }\end{array}$ & "Ram " \\
\hline+ & 94 & 198 \\
- & 967 & 2,674 \\
\hline
\end{tabular}

\section{Method}

Apparatus.-The necessary apparatus is readily found in any laboratory and is not expensive.

Sera.-The sera must agglutinate cells in saline suspension. They must be free of coagula. While weak sera may be used, it is better to use an avid serum with a titre of 
32 or more, and dilute it with saline to a titre of 8 . Anti-A and B we neutralize by Witebsky's A and B substance.*

Capillary Tubes.-We use capillary tubes such as are sometimes used to determine clotting time. They are approximately $3 \frac{1}{2}$ in. long, with a bore of roughly $0.4 \mathrm{~mm} . \dagger$ These we buy in bulk, $15 \mathrm{lb}$. at a time. A capillary is used only once and thrown away.

Agglutination Stand.-What is needed is something to seal the lower ends of the capillaries and to hold them at an angle of $\mathbf{4 5}$ degrees. We use a home-made holder, costing about $\$ 1$, made of thin building-board, in the form of a box $15 \mathrm{in}$. long $\times 4$ wide $\times 4$ high (Fig. 1). The lights in the box are for illumination, not for warmth. The plasticine along the lower edge of the opal glass is to seal and hold the capillaries. Discombe and Meyer (1948) also describe a simple apparatus.

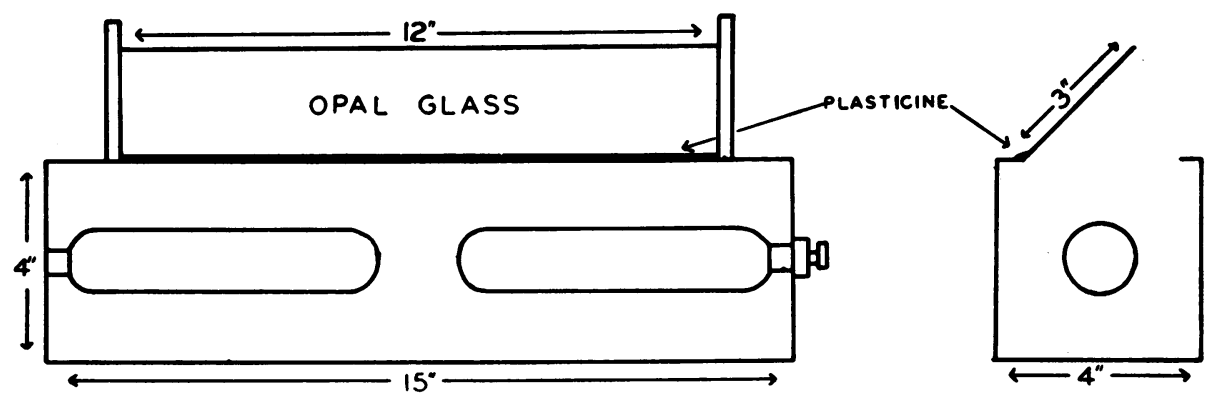

FIG. 1.-Diagram of agglutination stand.

Preparation of Cells.-For single tests-for example, at the bedside-or for emergency Rh-typing when transfusion is urgently required, the finger is pricked and a drop of blood expressed. A drop of citrate or oxalate, two or three times its size, is placed beside it, and mixed.

For routine laboratory use, and particularly when large numbers of samples are to be tested, oxalated, citrated, or heparinized blood or cells freed from clotted blood may be used. One or two large drops of blood are dropped into a small test-tube (say, $1 \times 9 \mathrm{~cm}$.; it must be shorter than the capillaries), and filled with saline, using at least 10 volumes of saline to 1 of blood. The mixture is centrifuged briefly to throw down most of the cells but not to pack them, and the saline is poured off quickly. We have developed a quick flip at the end of the pour that gives just the right suspension. It is a matter of practice and of habit, although there is some latitude as to the final suspension that will give sharp results, say 20 to $40 \%$. If saline-diluted serum is to be used the red cells need no further treatment : the drop or two of suspension in the bottom of the tube is what you want. If whole serum is to be used repeat the washing twice.

Loading and Setting up the Capillary Tubes.-The agglutinating serum should be in a container less deep than the length of the capillaries - for example, a small test-tube or bottle. The tip of the capillary is dipped in the serum and $\frac{1}{2}$ to $1 \mathrm{in}$. of serum allowed to run in. The capillary is placed on the table on a gentle slope, serum-filled end down. By so doing you prevent air from following the serum in. The process is repeated until you have six to 10 such serum-containing capillaries lying on a slope, parallel to one another,

* Kindly supplied by Sharp and Dohme (Canada) Limited, 1100 O'Connor Drive, Toronto 13, Ontario.

$\dagger$ Baird and Tatlock have sent us sample capillary tubes which ware quit a satisfactory. 
but a little apart. Now the first capillary is picked up in one hand and the test-tube containing the first red cell suspension in the other. With the latter on a fairly long slant, the serum-filled end of the capillary is dipped into the red cell suspension and an amount of the suspension roughly equal to the serum is allowed to run in. The capillary tube is turned red-cell-end up and the other is stuck in the plasticine with the capillary lying against the glass. The procedure is repeated with the next capillary and the next blood, and so on.

For a single test serum is taken up in the same way and then the serum-filled end is dipped into the mixed oxalated blood. The capillary is turned red-cell-end up and the other end is stuck at an angle of $\mathbf{4 5}$ degrees in a lump of plasticine. This is carried back to the laboratory along with such other specimens as you may be taking-for example, blood for haemoglobin, ABO-grouping, etc. There is a good chance that you can read your $\mathrm{Rh}$-grouping by the time you get back to the laboratory.

The Reaction.-Rh-positive cells set up against a saline-active $\mathrm{Rh}$ serum form into clumps, at first fine, then more or less quickly enlarging and appearing as cross bars with rather clear spaces in between. Eventually, the clumps will slide down towards the butt of the tube, and one will have left a solid butt with clear serum and saline above. Rh-negative cells form no clumps, but instead a long narrow ribbon or needle of cells along the back wall of the capillary, the ribbon or needle being thinner and more pointed above. The Rh-negative cells will stay thus for hours.

We read our Rh-positive reactions as soon as clumping is clearly visible, usually, with a good serum, within five to 10 minutes. Some cells react slowly with some sera, so that we do not make a final reading of Rh-negative until the end of an hour. You soon get to know your sera.

Some Minor Points.- If an air bubble gets locked between the serum and the cells, blow the contents of the capillary out on your thumb-nail, and then let the mixture run back into the capillary, and set it on the stand as usual. With experience these bubbles hardly ever occur.

If several sera-for example, anti-C, anti-D, anti-E, etc.- are to be used with one lot of cells, the cells may become contaminated by the earlier sera unless the following simple dodge is used : as you pick the capillary up in your right hand run the serum-filled end between the thumb and forefinger of your left to wipe off serum on the surface. After a time this motion will become automatic.

Do not keep the light on or it will make the glass too warm. Turn it on only to read the reactions

The method works well with blood several days old, provided it is freshly washed before testing.

\section{Errors in the Method}

False Positives.-These may be due to technical errors or to unrecognized antibodies.

Due to Technical Errors.-There will be no false positives if the directions are followed. They are practically all due to not washing the cells; once, if a diluted serum is to be used; thrice, if undiluted serum is to be used. Too high a concentration of serum or plasma in the capillaries may lead to clumping indistinguishable to the inexperienced from true agglutination. This is perhaps comparable to or identical with rouleaux formation. It can occur with some bloods if one simply sets a patient's unwashed cells up with his own serum. 
Due to Unrecognized Antibodies.-The test is so sensitive that traces of antibodies will occasionally give reactions by this method when they do not evidence themselves by the test-tube method. This has been true, for example, of specimens of anti-C antibody derived from anti-C $+\mathrm{D}$ by absorption of the anti-D. If this possibility is borne in mind new sera will be tested against appropriate panels of cells and, if necessary, further absorbed.

False Negatives.- If one is using a good serum, real false negatives never occur. If, however, one uses too dilute a suspension of cells, visible clumping will be delayed and the clumps will be so fine that they are not easy to see with the unaided eye. The error is readily avoided by not using dilute suspensions. If only a few cells are available for testing, one may get around the difficulty in several ways : removal of the saline from the washed cells by means of a fine capillary ; using a shorter column of serum and cells ; laying the tube down flat on the table for 15 minutes after the cell-serum mixture is in it, before putting it up on the slant.

\section{Advantages of the Method}

Economy of Serum in Any Laboratory.-About 100 tests can be done with $1 \mathrm{ml}$. of serum. If the serum is avid it may be diluted to give several hundred tests per $\mathrm{ml}$.

Economy of Man-power in Public Health Laboratories.-For nearly four years $\mathrm{Rh}$-typing and search for and titration of antibodies have been offered as a free public health service for all pregnant women in Manitoba. Using the capillary method for Rh-typing and for discovery and titration of saline antibodies, and the short modification (Chown, Lewis, and Bryce, 1948) of the Diamond-Denton method for albumin antibodies, one technician can do all routine pregnancy testing for a population of $1,000,000$. This includes, in addition to Rh-typing of all pregnant women, and of the husbands of the Rh-negative women, phenotyping of all the family of pregnant sensitized women, as well as periodic titration of maternal antibody.

Economy of Time in the Clinical Laboratory.- $\mathrm{Rh}$-typing is commonly done in connexion with transfusions, pregnancy, or disease in newborn babies. Ordinarily the typing may be done with deliberation. Upon occasion speed is important. As indicated above, most Rh-positive bloods will declare themselves in five to 10 minutes, while, by using the single test, bedside method, Rh-typing can often be completed by the time one has set up his ABO-grouping.

Economy of Methods. - We have found the method useful with antisera of the following specificities : D, C, Cw, c ; E, e ; K, k ; S ; Lu ${ }^{\mathrm{a}} ; \mathrm{Jk}^{\mathrm{a}}$; Le ${ }^{\mathrm{a}}$. Some sera, that others have reported to agglutinate only albumin-suspended cells or contain antibodies demonstrable only by the indirect Coombs technique, we have found to agglutinate saline-suspended cells by the capillary method. This allows a saving of time, temper, money, and rare sera.

\section{Summary}

The slanted capillary method in our hands has proved to be accurate. It is rapid in itself and, being exceedingly simple, allows the testing of many blood specimens a day. It is economical of serum. It may be used, not only with anti-Rh sera, but also with a number of others. 


\section{REFERENCES}

Bertinshaw, D., Lawler, S. D., Holt, H. A., Kirman, B. H., and Race, R. R. (1950). Ann. Eugen. Camb., 15, 234.

Chown, B.'(1944). Amer. J. clin. Path., 14, Tech. Sect., 8, 114.

- - and Lewis, M. (1946). Canad. med. Ass. J., 55, 66.

- - - and Bryce, A. (1948). Ibid., 59, 379.

- - and Peterson, R. F. (1951). In the press.

Peterson, R. F., Lewis, M., and Hall, A. (1949). Canad. J. Res. (E), 27, 214.

Discombe, G., and Meyer, H. (1948). Journal of Clinical Pathology, 1, 73.

Dunsford, I. (1949). Nature, Lond., 163, 962.

Levine, P., Backer, M., Wigod, M., and Ponder, R. (1949). Science, 109, 464.

Mollison, P. L., Mourant, A. E., and Race, R. R. (1948). Med. Res. Coun. Memo. 19.

Pickles, M. M. (1949). Haemolytic Disease of the Newborn. Springfield.

Poole, J. C. F., and Williams, G. C. J. (1951). Journal of Clinical Pathology, 4, 55.

Race, R. R., Mourant, A. E., Lawler, S. D., and Sanger, R. (1948). Blood, 3, 689. 